Digital Press Social Sciences and Humanities

The Involvement of Local People and Culture in Mesastila Resort and Spa, Magelang, Indonesia

Tuti Elfrida and Anik Nuryani

Proceeding of Indonesia Heritage Tourism Forum 2019 (IHTF 2019)

Dewi Pratika Ayu Dhira Pradati (eds) 


\title{
The Involvement of Local People and Culture in Mesastila Resort and Spa, Magelang, Indonesia
}

\author{
Tuti Elfrida*, Anik Nuryani \\ Diploma Tourism Program, Vocational College, Universitas Gadjah Mada, Yogyakarta, Indonesia \\ *e-mail: tutielfrida@ugm.ac.id
}

\begin{abstract}
Mesastila Resort and Spa is one of the tourist accommodations in the middle of the countryside and has a relatively high level of foreign visitors. Interestingly, there are several daily activities that involve culture and local people living around the resort. Those activities are managed and presented at the resort to be attended by guests staying at the resort The research explores data about the practice of involvement of local people and culture. Furthermore, this research also looks at the experience of local people in their involvement in providing service at tourist accommodation. The observation was carried out by participating in all activities involving local communities and looking at how local communities in this context host the guests and visitors. Meanwhile, interviews were also conducted with the local communities involved and management staff. The result of this study confirms that local culture and community are able to become an important element in providing activities and attractions within the scope of tourist accommodation. In addition to being economically profitable, it is possible for Richard to have a transfer of knowledge and cultural exchange from contacts between 'hosts' and 'guests' in every activity that exists. Local people also claim to be proud to be involved in the activities, as having a wider network, such as foreigners. Moreover, they are proud that their culture can be known and learned by people from other cultures.
\end{abstract}

\section{Keywords}

community involvement, tourist accommodation, tourist activities, tourist attraction

\section{Introduction}

Tourism is a highly developed industry, especially in Indonesia. Each sector in tourism improves itself in order to increase tourist visits to an area. Each tourist object and destination starts to explore its potential and promote its attraction. The transportation sector also expands facilities by adding more vehicles and building facilities. Tourism and local communities are inseparable like two sides of a coin. Local people become one of the reasons for tourists to travel, to have experience of the 'way of life' of other communities (Richard \& Hall, 2000). Changes that occur in the tourism industry have an impact on local communities and vice versa. The development of the tourism industry is always accompanied by an increase in the local community's welfare. The spaces available in the tourism sector are filled by the public, for example in the culinary field, tourist accommodation, transportation, and other travel businesses.

Involving local people in local industries takes them out of poverty, as Beeton (2006) calls Pro-Poor Tourism. Pro-poor Tourism that has an impact on the welfare of local communities cannot be defined simply from an economic perspective. As in impact, local people certainly have increased capacity in relation to physical conditions, psychological, mindset, and environmental factors (Beeton, 2006). There are at least three forms of benefits from pro-poor tourism concept as presented in the table below: 
Table 1 Advantages of Pro-poor Tourism Concept

\begin{tabular}{|c|c|c|}
\hline Economic Benefit & Non-Financial Livelihood Impacts & Participation and partnership \\
\hline Expand local employment and wages & Capacity building, training & $\begin{array}{l}\text { Create a more supportive } \\
\text { policy/planning framework that enables } \\
\text { participation by the poor }\end{array}$ \\
\hline Expand local enterprise opportunity & Mitigate environmental impacts & $\begin{array}{l}\text { Increase participation of the poor in } \\
\text { decision making by public and private } \\
\text { sectors }\end{array}$ \\
\hline Tourism service suppliers (food, etc..) & Address competing use of natural resources & $\begin{array}{l}\text { Build a pro-poor partnership with the } \\
\text { private sector }\end{array}$ \\
\hline $\begin{array}{l}\text { Those who sell to tourists (craft, art, } \\
\text { guides, etc) }\end{array}$ & Improve social and cultural impacts & $\begin{array}{l}\text { Increase the flow of information and } \\
\text { communication between stakeholder }\end{array}$ \\
\hline $\begin{array}{l}\text { Develop collective income sources } \\
\text { (fees, revenue, shares, equity } \\
\text { dividends, donations, etc..) }\end{array}$ & $\begin{array}{c}\text { Increase local access to infrastructure and services } \\
\text { provided for tourist (roads, communications, } \\
\text { health care, transport) }\end{array}$ & $\begin{array}{l}\text { Lay the foundation for future, ongoing } \\
\text { dialogue }\end{array}$ \\
\hline
\end{tabular}

Increasing prosperity and poverty alleviation through tourism are steps to empower local communities, as well as a sustainable tourism development program. Sustainable tourism is considered to lead to the management of all resources in certain ways so that economic, social, and aesthetic needs can be met while maintaining cultural integrity, essential ecological processes, biodiversity, and other life support systems (UNEP \& UNWTO, 2005).

The step to empower local communities through the tourism industry was also developed by Mesastila, one of the resorts located in Magelang Regency. It was formerly known as Losari Coffee Plantation and changed its name to Mesastila Resort in 2011. The location of the resort which is located in a rural area and close to local residents facilitates the relationship between the resort and the local community. In practice, this empowerment is seen through Mesastila's steps in recruiting local people to be employed at the resort. Approximately 75 percent of staff who work in Mesastila are local residents who are natives and live in villages around Mesastila. They fill positions as housekeepers, frontline, and staff in foodservice. In addition, local people are also involved in the cultural activities offered by Mesastila for guests who stay overnight, such as learning to dance, learn to make batik, and play gamelan. As coffee becomes one of the main assets owned by the resort, the coffee plantation tour, which is also offered to the guests, is taking local residents as human resources.

In this framework, local people are then invited to come into the world of tourism and hospitality and master various competencies and skills related to service and hospitality. They must behave and work according to the standards and procedures that are applied at Mesastila Resort and Spa. They inevitably have to master fields in tourism and hospitality, which they may not have worked out before. Learning and mastering these competencies certainly requires a process, which may not be short, especially if they have no background at all in the fields of tourism and hospitality. Nevertheless, it cannot be denied that the involvement of local residents in the tourism industry is able to make a real contribution to empowering, prospering, and increasing the community's capacity. More specifically, this paper discusses the practice of involving local people by Mesastila Resort and Spa in the agenda of community empowerment, including the advantages owned by the villagers in such complementary activities.

\section{Methods}

This research was conducted from March to August 2018. The research was carried out by participating in the activities in Mesastila which involve local villagers. The authors observed how these activities are carried out and how they can become additional attractions and activities in Mesastila. In addition to observation, research was also conducted by interviewing local villagers who work in Mesastila, as well as interviewing management staff in Mesastila, such as Human Resources Manager. From the management staff, the interview was directed to get the data about efforts to manage the human resources, especially the villagers who are invited to perform activities. Meanwhile, interviews conducted with local communities were getting the data regarding the experience and impact of this involvement on their lives. With unstructured interviews, the authors mostly conducted interviews at the workplace when the informant performed the activities in Mesastila Resort and Spa. 


\section{Finding and Discussion}

\subsection{In-house Activities of Mesastila and the Local People Involvement}

As part of the hospitality industry, tourist accommodation employs human resources that have diverse competencies to meet excellent service standards. These services provided also sometimes exceed the quality standards in order to attract tourists to stay and feel the leisure experience. Some even offer additional activities that can be done or enjoyed by guests in the hotels or resorts, such as those found at Mesastila Resort and Spa. Mesastila Resort and Spa offers In-House Activities inside the resort that can be attended by every guest or visitor. Interestingly, the in-house activities provided by the resort are more like attractions that present the involvement of local people who live around the resort. These additional attractions are cultural activities, especially Javanese, such as traditional dances, gamelan, janur, pencak silat, batik, and traditional jamu serving. Local people who practice these activities are present at the Mesastila Resort only when the activities take place at the scheduled time.

\subsection{Traditional Jamu Serving}

As one of the customs and traditions, especially among Javanese, jamu is still widely consumed by the community, both young and old generation. Even at Mesastila Resort and Spa, jamu is presented as one of the beverages when the guests enjoy breakfast at Java Red Restaurant. The jamu is served in glass bottles which neatly arranged in a bamboo basket. By pouring this beverage into the glass, each guest can smell the aroma and taste of the essence of natural ingredients, which are a mixture of roots, stems, fruits, seeds, flowers, and leaves.

The jamu is made by a middle-aged woman who lives in the village around Mesastila. She used to carry bottles containing jamu from a traditional kitchen in a corner of the coffee plantation with a bamboo basket on his back to the Java Red Restaurant. Interestingly, the lady is also the one who serves jamu for the guests from 7 to $10 \mathrm{am}$. This lady has been a worker at the resort since the 1990s and she used to wear classic kebaya and jarik cloth, and neatly curl her hair which began to turn white. Any interested guest can participate in the lady's activities, from preparing the jamu to serving it in the restaurant.

\subsection{Coffee Plantation Tour}

Coffee plantation which is the origin of Mesastila Resort and Spa's development and occupies half of the entire area becomes another attraction on offer. The plantation area, which was initially named as Losari Coffee Plantation and is dominated by Robusta coffee plants, has been one of the attractions and activities that can be enjoyed by every guest. In these 11 hectares of coffee plantation, guests are treated to a short tour for the introduction of coffee plants and cultivation, including the types of coffee plants and their differences, as well as the processing of coffee beans from drying, stripping, roasting, and grinding. The coffee plantation tour, which is guided by one of the staff at Mesastila Resort, takes about an hour in English for foreign guests and Bahasa Indonesia for domestic guests.

At the end of the tour, guests will be invited to stop by the coffee bean processing house. The building of this house seems traditional and simple with the dominance of wood and bamboo as its building material. At this coffee bean processing house, guests may have a chance to meet and interact with local residents (generally living around the resort) who work every day to take care of the coffee plants, picking coffee beans, and processing the coffee beans. The whole steps of processing beans are done traditionally with traditional equipment as well. In the coffee processing house, the local residents carry out their duties in certain rooms that have been provided, so that each guest can look at the series of coffee bean processing.

The coffee processing house also functions as a coffee shop with several benches and wooden tables to enjoy coffee brewing for guests at the end of the tour. The coffee drink is prepared and served by a lady who usually wears a traditional long-sleeved Javanese kebaya and jarik cloth that covers her legs. Not only warm coffee drinks are served on the table, but also coffee candy, the name for black coffee beans, and brown sugar which are consumed by chewing them together. 


\subsection{Batik}

As one of the Javanese cultural heritages, batik is also presented as one of the activities in Mesastila Resort and Spa. The batik activity takes place every Monday and Saturday from 2 to 4 pm. The batik activity takes place in the Joglo Gamelan of Mesastila Resort and Spa and is carried out by a female batik artist. She is a resident who lives about 2 kilometers from Mesastila Resort and Spa and is engaged in her batik skills in a small scale batik home industry in the village of Losari. She was then invited by the Mesastila Resort and Spa to perform in batik class.

With all the batik equipment, the lady presents at Mesastila Resort and Spa and arranges the equipment neatly, such as small stove with a small frying pan on it to melt the dough (the main ingredient in making batik), canting, white cloth that has been patterned with a pencil, several pieces of cloth that have been made into batik cloth perfectly before (used as a result example of the process in making batik) and are arranged on a wooden shelf. It appears that the lady prepares two different types of batikpatterned fabrics, one of which is a fabric that is a batik by herself (usually the fabric that is indeed her work for later sale) and another batik-patterned fabric provided for guests who want to learn batik. Within two hours, the lady practices batik, and occasionally guests want to know the batik activities, as well as learn how to make batik on a certain pattern of the fabric. At that moment, the interaction between guests and the villager occurs. The batik lady slowly explains how to make batik, from taking the liquid dough from the pan with a canting to applying it on the fabric according to the pattern that was drawn.

\subsection{Janur}

Janur is a Javanese word for coconut leaf, which is used as a tool for daily life in many areas in Indonesia, especially Java. The janur is usually used for big celebrations in Javanese cultures, such as the wedding ceremony. The activity of arranging janur which is presented on Wednesday and Sunday from 2 to $4 \mathrm{pm}$ in Mesastila Resort is also practiced by the same lady as batik class. On a predetermined schedule, the lady carries the equipment and needs to arrange the leaves, including the banana tree trunk. During these two hours, she will string the janur by herself, from cutting the leaves in various shapes and patterns to sticking them in the trunk of a banana tree. Just like batik, guests at Mesastila Resort and Spa can take part in this activity, as well as learn to arrange those leaves. The perfectly arranged janur will be placed at Joglo Gamelan and will be ornaments and decorations to beautify the room.

\subsection{Javanese Dance}

Javanese Traditional Dance activity takes place at Mesastila Resort and Spa also involves a contribution from the local villagers. This activity actually resembles a dance studio that exists in several regions in Indonesia, which has a function as a center for learning traditional dance. At Mesastila Resort and Spa, this traditional Javanese dance practice is taught by a trainer who has the competence and experience in such art and takes place in Joglo Gamelan. Meanwhile, the trainees are little girls who also come from and live in the area around Mesastila Resort and Spa. The activity which lasted for two hours on Tuesday and Thursday is attended by around 12 participants, who present to master a certain type of dance. Each participant brings their dancing equipment, such as scarves, umbrellas, traditional jugs, or other equipment used for dance.

Javanese traditional dancing activity is not directly intended to be participated or watched by guests in Mesastila Resort and Spa. However, the guests are welcome to learn or to just watch, as the coach gives room for such purposes. On some occasions, a group of little girls who practice this traditional dance is also asked to perform in a more formal way, especially when Mesastila Resort has a special agenda or celebration. Either the trainer or the resort does not charge fees for participants to learn and practice dancing.

\subsection{Gamelan}

Among activities offered at Mesastila Resort and Spa, gamelan activity requires the most personnel. Eleven people from local residents play the gamelan device consisting of several instruments. Gamelan activity only takes place on Fridays from 2 to $4 \mathrm{pm}$ and also takes place at Joglo Gamelan. A set of gamelan is available at Joglo Gamelan in Mesastila Resort, so gamelan players do not need to bring their own 
equipment from home. During those two hours, they play some Javanese music and songs, with some short breaks between two songs.

Just like other complementary activities, Gamelan class can also be followed by guests staying at Mesastila Resort and Spa. Generally, they only watch Gamelan performances by the villagers, while enjoying foods and beverages from Java Red Restaurant which is right next to Jogo Gamelan. However, sometimes some guests also want to ask question about Gamelan as a Javanese instrument or also want to try playing it. If interested, the local residents will be happy to train guests who want to play the Gamelan.

\subsection{Pencak Silat}

Pencak Silat or Indonesian Martial art is a traditional form of exercise and a powerful way to create the speed and gain control of the body. This martial art is practiced by a Javanese man who has expertise and skill in this martial art. Pencak Silat activity at Mesastila Resort and Spa takes place every Monday, Wednesday, and Thursday for one hour, starting from 3 to $4 \mathrm{pm}$. In contrast to other activities, Pencak Silat takes place at Sasana Yoga, a pavilion building that is located slightly apart from other buildings at Mesastila Resort and Spa in order to provide calmness while doing the exercises.

Guests who are interested in participating in Pencak Silat activity may contact the resort staff or come directly to the venue on the scheduled day and time. Since guests have a short duration of time to stay at the resort, the coach only teaches basic techniques, especially those which are useful for self defenses. However, it is not uncommon for Pencak Silat trainer to get a special request to train guests for more comprehensive techniques in the martial arts, even though it takes a relatively longer time. On that occasion, the interaction became more intensive, even in some cases resulting in close friendship and brotherhood. If indeed there is no guest who is interested in learning Pencak Silat, then he will still be present at Sasana Yoga to do independent exercises to improve his abilities and skills.

\subsection{The Local People Experience and Advantages in Participating in the In-house Activities}

The local people involvement in activities of the tourism and hospitality industry leads to certain impacts for local people, both directly and indirectly. The economy is one of the impacts among villagers who are invited to take part in the Mesastila Resort and Spa, as they are able to meet the household needs by receiving income from the activities they participate in. Not infrequently, they also get tips from guests as they kindly share knowledge and experience. In fact, a trainer of activity at Mesastila Resort claimed to have been helped by a former resort guest when he needed money for his son's treatment. In this context, the economic benefits gained by villagers are accompanied by social benefits. In other words, they have a network of interactions with resort guests, the majority of which are foreigners from various countries.

Their participation in Mesastila Resort and Spa also brings a certain pride. During this time, the resort is considered to be an exclusive and luxurious place that cannot be reached by everyone. The In-house activities let the practitioners have an entry permit and let them feel proud to be part of the hospitality and tourism industry which stands in the middle of their village. Becoming cultural ambassadors is another pride among villagers who present Javanese arts and cultural products for international citizens. They realize the international visitor's interest in learning Indonesian art and culture, especially Javanese. These contacts and interactions with foreign tourists become a source of pride among them, as foreigners are often considered superior. The brief interaction that is developed between local residents and guests also leads to sharing knowledge and experience and the realization of cultural exchange. Not infrequently, for example, pencak silat trainer gets new knowledge and techniques from guests who have prior knowledge of martial arts.

As an industry that prioritizes hospitality, Mesastila Resort and Spa applies certain rules and Standards Operating Procedures that must be obeyed and implemented by all staff and human resources involved, including those in complementary activities. From these rules, they are then accustomed to professionalism, discipline, time management, grooming standards, cleanliness standards that they apply when they work in the resort. The increased economic level and contact with tourists lead to an increase in living standards, such as investment in education by sending children to higher education. The involvement of local residents in Mesastila Resort and Spa also built a network with employers and management staff. Some workers seem to involve their siblings or children in participating in work and activities at the resort. Activities that are carried out regularly also have an impact on the acquisition of 
experience and knowledge transferred from the employers which benefits their professional lives as well as their daily lives.

Table 2 Advantages among local people who participate in the Mesastila Resort and Spa's Activities

\begin{tabular}{|c|c|}
\hline $\begin{array}{l}\text { a. Within themselves } \\
\text { - Economic } \\
\text { - } \quad \text { Living standards } \\
\text { - } \quad \text { Capacity building }\end{array}$ & $\begin{array}{l}\text { b. Within the guests } \\
\text { - Knowledge \& Experience } \\
\text { - Pride } \\
\text { - Network }\end{array}$ \\
\hline $\begin{array}{l}\text { c. Within the community } \\
\text { - Pride } \\
\text { - Prestige }\end{array}$ & $\begin{array}{l}\text { d. Within the employer } \\
\text { - Knowledge \& Experience } \\
\text { - } \quad \text { Network }\end{array}$ \\
\hline
\end{tabular}

\subsection{Tourism and the Agenda of Empowering Locals}

In the context of sustainable tourism development, the community becomes one of the important elements that plays a decisive role. Local people as cultural heirs have a positive contribution to become a source of knowledge transfer with the outsiders, including foreign visitors. As tourism relies on visiting places and people, the tourism and community should work collaboratively and simultaneously. Consequently, tourism is one of the most significant communities development tools, particularly in marginal or peripheral communities such as remote and rural communities (Beeton, 2006).

Another purpose of taking the local community into the tourism and hospitality industry is to avoid the antagonistic attitudes of the locals toward the developer (Madrigal, 1994). The intention to avoid antagonism of local residents also seems to have formed at Mesastila Resort and Spa. The 22 hectares area of the resort is only fenced in the front. There is no clear boundary line between the resort and nonresort areas, considering that there are only plantations or rice fields either owned by the resort or owned by villagers. Inviting residents to participate in work and activities at Mesastila Resort and Spa is one of the negotiating strategies so that residents can also participate in supporting the development of the resort.

The response and support of local communities towards the development of the tourism and hospitality industry can be varied. Leslie states that there are at least 4 factors influencing the attitudes and responses of local residents to tourism development, namely length of residence, economic dependency, age, and level of contact with tourists (Leslie, 2005). From the case study of the involvement of villagers in employment at Mesastila Resort and Spa, the economic dependency factor dominates their attitudes and responses in resort development. The wages earned from working for complimentary activities at Mesastila resort contribute to the household economy used for daily needs. Villagers then have an alternative income, in addition to the on-farm income source. Goodwin also states that the employment of the poor in tourism enterprises could be one of the easiest ways of pro-poor tourism strategies to benefit the poor in securing household cash income (Goodwin, 2007). Tourism is then seen to generate economic impact, such as employment, income, improved living standards, economic diversification, widening economic opportunities, and stimulating investment (Fernandes, 2013).

In addition to economic, socio-cultural impact also play a role among those villagers. It can be seen that the guests at the resort are interested in joining and learning the cultural activities that are supported by some villagers and offered by Mesastila Resort and Spa. The interest of tourists in local culture can result in the conservation and sometimes the revitalization of traditional arts, traditional festivals, handicrafts, folklore, customs, ceremonies, and certain aspects of traditional lifestyle (Richard, 2005). The fact that the foreigners come and appreciate the local customs and environment and share the life of the community can be re-valued in local people's eyes of their own traditions. However, the development of tourism might lead to the renewal of a sense of cultural pride by residents and this renewal can be strengthened when local people observe tourists appreciate their culture (Jurowski, 2007). Appreciation from these outsiders then motivates local residents or cultural owners to further preserve their assets and cultural heritage. Expression of pride also appeared not only from the appreciation of foreigners towards the local culture but also from the network established between villagers with employers and foreign visitors. Opportunities that are not owned by each of the community members then make the residents involved in the complementary activities have a bargaining position among others in the area. At the very least, the positive impact of local people's participation in the development of the tourism industry can be felt in several areas, including employment opportunities, language skills, income and standards of living, opportunities for learning more about other nations, 
opportunities for meeting interesting people, quality of life, attitude toward work, conservation of cultural heritage, and cultural identity (Rátz, 2000).

Besides the benefits of the villager's involvement in the tourism and hospitality industry, there are some negative potentials that need to be anticipated. The involvement of only a few people at Mesastila Resort and Spa has the potential to create social jealousy which may lead to disintegration and conflict within the community. If so, the relationship between the developer and the community becomes tenuous and distant, which would interfere with the ongoing development of the tourism and hospitality industry.

\section{Conclusion}

The agenda of community empowerment while preserving local culture by Mesastila Resort and Spa can go hand in hand and complement each other. Guests who are interested in participating in the complementary activities offered by the resort can even gain knowledge and hands-on experience from competent experts who are present to support those in-house activities. Interaction between guests, which among them are foreigners, with villagers or native inhabitants raises cultural exchanges that influence self-development, both by guests and hosts. A pride arises when villagers can represent the community to display their art and cultural heritage in the national and international arena. Also, the network is one of the advantages of the involvement of local residents in the activities and employment in Mesastila. The economic impact will certainly be the dominant element that follows the socio-cultural impact embraced by the villagers.

The presence of local residents to practice certain activities and at some moments only become the background of other activities then put the local residents as objects. More interactive activities will greatly help the effectiveness of cultural exchange and knowledge transfer between hosts and guests. In addition, each in-house activity offered will be better equipped with a guide book to give guests a comprehensive understanding of what is seen, heard, and learned. Every local people involved will also be better if equipped with foreign language skills. If such a requirement is hard to be realized, then the resort should assign one of the staff to be in charge of existing activities, which if needed also acts as a translator, so that interaction, as well as the conversation between hosts and guests, will be more directed.

The openness of Mesastila Resort and Spa by recruiting human resources from local residents who live in villages around the resort to work and do activities can be a role model for community empowerment as well as a social responsibility form of sustainable tourism and hospitality industry. This step is concrete action and effort to prosper the lives of local people and improve living standards. Industry's collaboration with local residents can be enhanced by designing several programs or activities, both inside and outside the resort, to increase attraction for guests who visit while increasing resort occupancy and increasing revenue. Furthermore, the more people involved, the more equitable impacts on people's welfare. The advantages gained from industry and local community collaboration can then take place more sustainably.

\section{References}

Beeton, S. (2006). Community Development trough Tourism. Collingwood: Landlinks Press.

Fernandes, C. (2013). The impact of cultural tourism on host communities Cultural Tourism. In R. Raj, K. Griffin, \& N. Morphet (Eds.), Cultural Tourism (pp. 26-38). Oxfordshire: CAB International.

Goodwin, H. (2007). Indigenous tourism and poverty reduction Tourism and Indigenous Peoples: Issues and Implications (R. Butler \& T. Hinch, eds.). Oxford: Elsevier Butterworth-Heinemann.

Jurowski, C. (2007). Tourism and intercultural exchange. Annals of Tourism Research, 34, 551-552.

Leslie, D. (2005). Effective community involvement in the development and sustainability of cultural tourism: an exploration in the case of New Lanark. In M. Sigala \& D. Leslie (Eds.), International Cultural Tourism: Management, Implications and Cases (pp. 122-136). Oxford: Elsevier Butterworth-Heinemann. 
Madrigal, R. (1994). Residents' perceptions and the role of government. Annals of Tourism Research, 22, 86102.

Rátz, T. (2000). Residents' perceptions of the socio-cultural impacts of tourism at Lake Balaton, Hungary. Tourism and Sustainable Community Development, 7, 36-47.

Richard, G. (2005). Textile tourists in European periphery: new markets for disadvantaged areas. Tourism Review International, 8, 323-338.

Richard, G., \& Hall, D. (2000). The community: A sustainable concept in tourism development. Tourism and Sustainable Community Development, 12, 48-59.

UNEP, \& UNWTO. (2005). Making Tourism More Sustainable -- A Guide for Policy Maker. World Tourism Organization. 